\title{
KERAJINAN KAIN ETNIK PEGRINGSINGAN DI DESA TENGANAN KECAMATAN MANGGIS KABUPATEN KARANGASEM BALI
}

\author{
N.K. Seminari ${ }^{1}$ I.N. Puja ${ }^{2}$, A.A. R. Remawa ${ }^{3}$, dan N.M.I. Muliyati ${ }^{4}$
}

\begin{abstract}
ABSTRAK
Pengabdian masyarakat bertujuan untuk meningkatkan produktivitas kerajinan tenun etnis. Kegiatan operasional meliputi: (1) Pelatihan dalam manajemen bisnis (pemasaran, produksi, keuangan dan pembukuan); (2) Pelatihan operasional peralatan tenun bukan mesin yang efektif; Hasil penelitian menunjukkan bahwa pengabdian masyarakat untuk meningkatkan produksi kain pegringsingan di Desa Tenganan, Kecamatan Manggis, Kabupaten Karangasem telah memberikan dampak positif bagi masyarakat karena memperoleh banyak pengetahuan dalam mengembangkan produksi kain tenun melalui diversifikasi desain, manajemen bisnis sehingga untuk meningkatkan manajemen dalam pemasaran, produksi dan keuangan, meningkatkan daya saing di pasar, dan tentu saja meningkatkan pendapatan bagi penenun.
\end{abstract}

Kata kunci : kerajinan, kain, etnik, pegringsingan, produktivitas

\begin{abstract}
The community service aimed to increase productivity of ethnic woven weaving crafts. Operational activities include: (1) Training in business management (marketing, production, finance and bookkeeping); (2) Operational training of weaving equipment is not an effective machine; The result show that the community service to improve the production of pegringsingan fabrics in Tenganan Village, Manggis District, Karangasem Regency has had a positive impact on the community because it gained a lot of knowledge in developing woven fabric production through design diversification, business management so as to improve management in marketing, production and finance, increasing competitiveness in market, and certainly increase income for weavers.
\end{abstract}

Keywords: craft, fabric, ethnicity, painting, productivity

\section{PENDAHULUAN}

Kain gringsing adalah satu-satunya kain tenun tradisional Indonesia yang dibuat menggunakan teknik teknik dobel ikat dan memerlukan waktu 2-5 tahun. Proses pembuatan kain gringsing dari awal hingga akhir dikerjakan dengan tangan. Benang yang digunakan merupakan hasil pintalan tangan dengan alat pintal tradisional, bukan mesin. Benang tersebut diperoleh dari kapuk berbiji satu yang didatangkan dari Nusa Penida karena hanya di tempat tersebut bisa didapatkan kapuk

\footnotetext{
${ }^{1}$ Dosen Fakultas Ekonomi Universitas Udayana kseminari@unud.ac.id

${ }^{2}$ Dosen Fakultas Pertanian Universitas Udayana

${ }^{3}$ Dosen ISI Denpasar

${ }^{4}$ Dosen ISI Denpasar
} 


\section{Dewantari dan I.G. Suranjaya}

berbiji satu. Setelah selesai dipintal, benang akan mengalami proses perendaman dalam minyak kemiri sebelum dilanjutkan ke proses ikat dan pewarnaan. Perendaman tersebut bisa berlangsung lebih dari 40 hari hingga maksimum satu tahun dengan penggantian air rendaman setiap 25-49 hari. Semakin lama perendaman, benang akan makin kuat dan lebih lembut. Buah kemiri (Aleurites moluccana) diambil langsung di hutan Tenganan dan pembuat kain gringsing harus menggunakan kemiri yang benar-benar matang, serta jatuh dari pohonnya. Benang akan dipintal menjadi sehelai kain yang memiliki panjang (sisi pakan) dan lebar (sisi lungsi) tertentu. Untuk merapatkan hasil tenunan, benang akan didorong menggunakan tulang kelelawar. Kain yang sudah jadi akan diikat oleh juru ikat mengikuti pola tertentu yang sudah ditentukan. Proses pengikatan menggunakan dua warna tali rafia, yaitu jambon dan hijau muda. Setiap ikatan akan dibuka sesuai proses pencelupan warna untuk menghasilkan motif dan pewarnaan yang sesuai.

Motif kain gringsing hanya menggunakan tiga warna yang disebut tridatu. Pewarna alami yang digunakan dalam pembuatan motif kain gringsing adalah 'babakan' (kelopak pohon) Kepundung putih (Baccaurea racemosa) yang dicampur dengan kulit akar mengkudu (Morinda citrifolia) sebagai warna merah, minyak buah kemiri berusia tua $( \pm 1$ tahun) yang dicampur dengan air serbuk/abu kayu sebagai warna kuning, dan pohon Taum untuk warna hitam. Selain bahannya yang langka, proses pembuatan kain ini juga terbilang amat rumit. Pekerjaan terumit adalah mengikat dan ini hanya dilakukan oleh seseorang dengan keahlian khusus di wilayah itu. Tidak sembarang orang bisa mengikat. Demikian juga dengan memberikan warna. Semua bagian dilakukan oleh orang-orang yang khusus dengan bagiannya.

Kain gringsing ini sendiri terbilang unik, otentik dan kini amat langka. Geringsing adalah produk tenun tradisional yang hanya dapat ditemukan di Tenganan. Gerinsing dianggap sakral yakni menjauhkan kekuatan magis jahat atau black magic. Geringsing diturunkan dari kata "gering" yang berarti sakit dan "sing" yang berarti tidak. Di Bali, berbagai upacara, seperti upacara potong gigi, pernikahan, dan upacara keagamaan lain, dilakukan dengan bersandar pada kekuatan kain gringsing.

Persoalan yang dijumpai terkait dengan produksi kain pegringsingan di Desa Tenganan Kecamatan Manggis Kabupaten Karangasem diantaranya: manajemen usaha yang hampir semuanya adalah berbentuk usaha perseorangan. Dalam operasionalnya UKM tidak melakukan usaha pisah harta, pembukuan dan akuntansi sehingga kurang dapat mengetahui jumlah laba yang sebenarnya, serta belum adanya tarif umum pengupahan tenaga kerja. Kesulitan bahan baku bahan pewarna alami dari tanam-tanaman yang sulit didapat (didatangkan dari luar pulau). Peralatan produksi (tenun) masih sangat sederhana (tradisional) dan kurang ergonomis sehingga produktivitas pengrajin rendah. Proses pewarnaan yang masih menggunakan peralatan sederhana sehingga boros bahan warna (banyak menempel didinding) tidak merata, dan perlu waktu lama. Varian dan desain produk yang monoton dan terbatas pada kain untuk sembahyang dan pakaian adat Bali. Pemasaran masih bersifat sederhana sehingga perlu dilakukan promosi untuk mengembangkan pasar.

\section{METODE PELAKSANAAN}

Berbagai persoalan yang telah teridentifikasi maka metode pemecahan masalah yang digunakan dalam kegiatan pengabdian kepada masyarakat ini antara lain (1) pelatihan manajemen pemasaran, produksi, keuangan, dan penentuan tarif standar pengupahan tenaga kerja. (2) Pelatihan operasional alat tenun bukan mesin yang lebih ergonomis; dan (2) Rancang bangun alat tenun bukan mesin tepat guna sesuai dengan kebutuhan tenun kain gringsing dan lebih ergonomis. (4) diversifikasi desain mengikuti selera pasar. 


\section{HASIL DAN PEMBAHASAN}

Kegiatan pengabdian kepada masyarakat ini dilaksanakan mulai tanggal 23 Juli sampai dengan tanggal 27 Agustus 2018 yang diterima oleh Bapak Kepala Desa Tenganan didampingi oleh semua kepala dusun di wilayah Desa Tenganan, diikuti oleh 30 orang mahasiswa KKN PPM dan tim KKN (DPL). Sebagai narasumber tentang bimtek desain kain adalah Dr A.A. Rai Remawa. dan Pelatihan manajemen oleh Ni Ketut Seminari,SE. M.Si. Narasumber untuk Bimtek dan pelatihan menenun secara ergonomis adalah Ni Made Ida Muliyati,SSn. M.Erg. dan pewarnaan bahan pewarna alami oleh Ir. I Nyoman Puja, MS dan beserta 30 orang mahasiswa KKN PPM yang selalu hadir dan mempersiapkan setiap kegiatan. Peserta sangat senang dan antusias mengikuti pelatihan, mereka cukup aktif melakukan diskusi untuk menambah pengetahuan dan berbagi dengan tim pengabdi, narasumber maupun dengan mahasiswa.
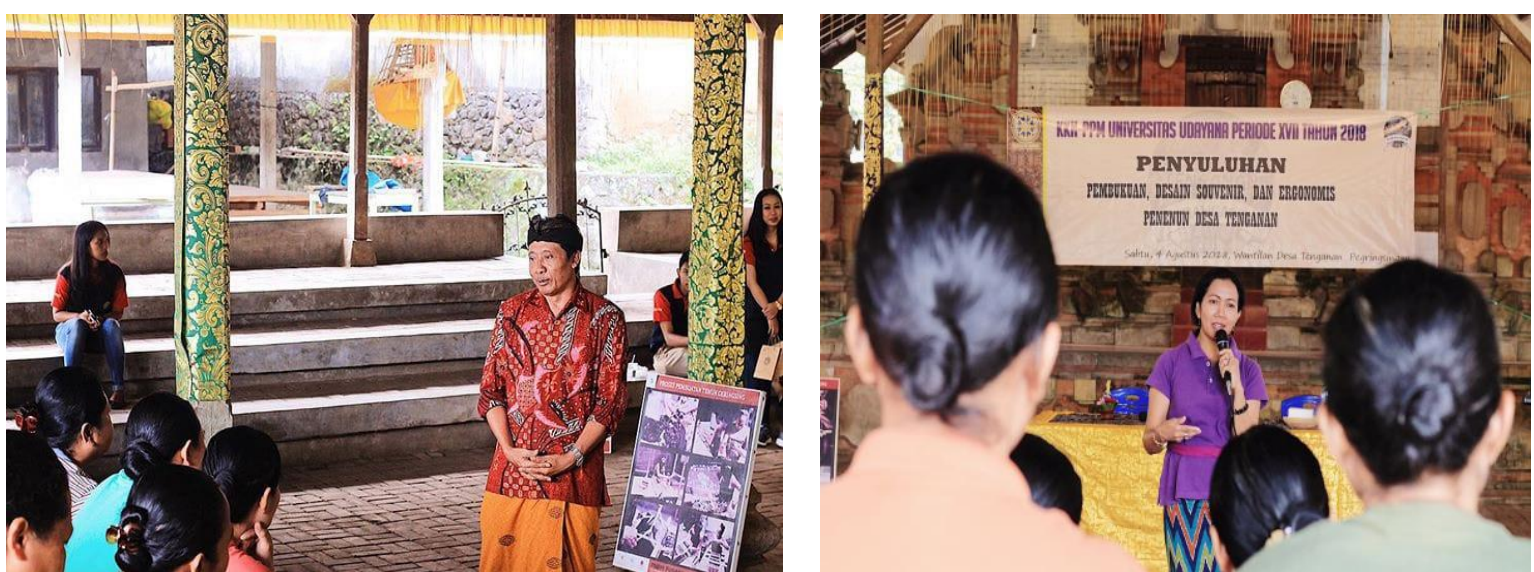

Gambar 1. Pelatihan pengembangan Desain dan Perbaikan pembukuan

Pada akhir kegiatan pengabdian masyarakat khususnya penenun merasa sangat senang karena mendapat pengetahuan yang sangat berharga bagi mereka terutama dalam mengembangkan produksi kain tenun dengan tehnik-tehnik menenun serta pengembangan manajemen sehingga nantinya dapat meningkatkan penghasilan mereka. Masyarakat Desa Tenganan sangat berharap kegiatan pengabdian kepada masyarakat ini dapat dilanjutkan untuk program pengabdian tahun berikutnya. Faktor penghambat yang dirasakan pada kegiatan pengabdian ini adalah menentukan jadual yang tepat untuk pelaksanaan sosialisasi maupun pelatihan karena banyaknya kegiatan di desa seperti upacara adat, mereka juga punya pekerjaan utama dan sampingan seperti : pedagang, dan petani.

\section{KESIMPULAN DAN SARAN}

\section{Simpulan}

Pengabdian masyarakat perbaikan produksi kain pegringsingan di Desa Tenganan, Kecamatan manggis kabupaten karangasem membawa dampak positif bagi masyarakat karena mendapat banyak pengetahuan dalam mengembangkan produksi kain tenun melalui diversifikasi desain, manajemen usaha sehingga dapat meningkatkan manajemen dibidang pemasaran, produksi, dan keuangan, meningkatkan daya saing di pasar, dan tentunya meningkatkan penghasilan bagi penenun.

\section{Saran}


Kegiatan pengabdian kepada masyarakat sangat diperlukan oleh masyarakat terutama penenun oleh karena itu sebaiknya dilaksanakan secara berkelanjutan .

\section{UCAPAN TERIMAKASIH}

Penulis mengucapkan terima kasih kepada KEMENRISTEK DIKTI atas dana yang diberikan lewat program KKN PPM, Rektor Universitas Udayana, Ketua LPPM beserta Staf,. Atas segala fasilitasi dalam pelaksanaan dilapangan, sehingga pengabdian kepada masyarakat terlaksana sesuai rencana.

\section{DAFTAR PUSTAKA}

Buku Pedoman Kuliah Kerja Nyata Pembelajaran dan Pemberdayaan Masyarakat, Universitas Udayana 2018.

Badan Perencanaan Pembangunan Kabupaten Tabanan, 2012 Rencana Pembangunan Jangka Menengah Kabupaten Tabanan.

Sardiana, I.K. and N.L.R. Purnawan. 2016. Indegenous Community, Ecotourism and Sustainability: Experience from Tenganan dauh Tukad traditional village. Preceding of The $3^{\text {rd }}$ International Hospitality and Taourism Coference (IHTC, 2016) and $2^{\text {nd }}$ International Seminar on Taourism (ISOT 2016) : CRC Press. Pp 591-595

Sardiana, I.K. and N.L.R. Purnawan. 2015. Community-based Ecotourism in Tenganan Dauh Tukad: An Indigenous Conservation Perspective. Jurnal Kajian Bali (Journal of Bali Studies). Vol. 5 No. 2. Pp. 347-368

Suwati Kartiwa, 2007, Ragam Kain Tradisional Indonesia Tenun Ikat, Jakarta: Gramedia Pustaka Utama. 